\title{
Impact of Public Capital Expenditure on Economy Growth of Nigeria
}

\author{
Jideofor Nnennaya Joy ${ }^{1}$, Michah Chukwuemeka Okafor ${ }^{1}$, Josephine Adanma Nmesirionye ${ }^{1}$ \\ ${ }^{1}$ Department of Accounting, Michael Okpara University of Agriculture, Umudike, Nigeria \\ Received: September 4, 2021 \\ Revised: September 29, 2021 \\ Accepted: October 18, 2021
}

\begin{abstract}
The research investigates the relationship between governmental capital spending and economic development in Nigeria. Several issues of the Central Bank of Nigeria's statistics bulletin were used in the research, which yielded a large amount of data. The data was submitted to a unit root test, which was performed using the Augmented Dickey fuller (ADF) method, in order to determine its time series characteristics. The variables' socioeconomic characteristics were obtained via the use of descriptive statistics. Because of the varying order of integration seen in the unit root, cointegration and regression analysis were carried out utilizing the ARDL- Autoregressive Distributed Lag method, which is an acronym for Autoregressive Distributed Lag. The results show that public capital investment has a negative and statistically significant $\left(\mathrm{t}_{\mathrm{cal}}=-2.6996\right)$ impact on the Nigerian economy, as assessed by the GDP growth rate, according to the data. The results demonstrate that when capital expenditures in Nigeria get the attention they deserve, they have the potential to contribute to economic development in the country. This research recommends that the government manage capital spending in an appropriate manner in order to enhance the nation's productive capacity and accelerate economic development in light of the results.
\end{abstract}

Keywords: Government Expenditure, Economic Growth, Economic Performance, Capital Expenditure, Autoregressive Distributed Lag

\section{Introduction}

In both emerging and developed nations, as well as in industrialized ones, there is a current common characteristic that works in combination with the well-known Wagner's Law of state spending, which is the increase in public capital expenditure. «Public capital expenditure has traditionally played a role in shaping the course and determining the state of economic development. By spending, the government preserves and promotes national identity, provides infrastructure for developing both the course and distribution of economic benefits, and provides social services to meet the basic needs of its population» (Tsauni, 2007).

The connection between public capital investment and the Nigerian economy, as well as the nature of its inclusive impact, have been a source of contention for many academics in recent years. In addition to the Wagner and Musgrave theories, the concept of increasing state operations, and Keynes's theory of deficit financing all stress how important it is for the government to spend more on public goods and services (Obi 2011). Governments, according to Keynesians, can reverse a nation's economic decline by borrowing money from the private sector and then returning it to them via a variety of spending initiatives. Furthermore, data from previous research suggests that an increase in Nigerians' socioeconomic and physical infrastructure expenditure has an impact on the country's long-run growth rate. Investing in health and education may, for example, help improve worker productivity, which in turn helps promote the development of national output. In a similar vein, infrastructure investment in sectors such as roads and electricity lowers manufacturing costs, increases profitability, and stimulates investment in the private sector, thus improving the performance of a country's 
government (Barro,1990,Roux, 1994, Okojie, 1995, Morison and Schwartz, 1996). The disparity between Nigeria's economic performance and the country's increasing capital investment has raised questions about the country's ability to play a role in the country's growth. In Nigeria, some academics believe that the connection between public capital investment and performance is weak or non-existent, while others argue that the relationship has varying degrees of causality in their ties with performance (Onakoya \& Osoba, 2012).

The huge profits produced by the production and sale of crude oil, as well as the increasing demand for public (utility) goods such as roads, communication, power, education, and health, have resulted in a rise in government expenditure in Nigeria. The need to guarantee the internal and external security of the people and the country is becoming more urgent. In accordance with the statistics available, overall government spending (both capital and recurrent) and its constituent parts have risen consistently during the past three decades. The total amount of recurrent spending by the government increased from N4, 805.20 million in 1980 to $\mathrm{N} 36,219,60$ million in 1990, and then to N1, 589,270.00 million in 2007 from N4, 805.20 million in 1980. However, government capital spending rose from N10, 163.40 million in 1980 to N24, 048.60 million in 1990, representing a tenfold increase. In 2000, capital expenditure amounted to N239,450.90 million, while in 2007, it amounted to N759,323.00 million. Over the period 1981 to 2015, capital expenditures grew in all of its components.

Unfortunately, increasing government expenditure has not resulted in significant growth and development, and Nigeria continues to be one of the world's most impoverished nations. Despite the advancement of technology, Nigerians continue to live in abysmal poverty, with more than half of the population subsisting on less than $\$ 1$ per day. As a consequence of failing infrastructures, such as electricity supply and roads, many companies have failed, resulting in a rise in unemployment, and elephant projects have been abandoned.

In order for a developing country to break free from the cycle of poverty, it must be able to sustain economic development.

When we talk about economic growth, we are referring to a rise in a country's potential gross domestic product (GDP), which differs depending on how national product is measured. In Nigeria, a number of macroeconomic indicators suggest that the nation has been struggling in the recent past. This includes variables like the balance of payments, import requirements, inflation rate, currency rate, and national savings, to name a few. This shows how important it is to determine if public capital expenditures have any impact on the country's economic development in order to make informed decisions. The main goal of the research is to achieve this.

\section{Literature Review}

Economic growth theory is concerned with the long-term or anticipated growth tendency of the economy (Branson, 2002). Rather than the components that led to economic growth, economic development is focused with the study of the mechanisms that allow certain economies to thrive quickly while others do not at all throughout time. Earlier growth theories put a greater emphasis on some sectors of the economy than others. Examples include the emphasis placed on trade surpluses by the Mercantilists, the Physiocrats' emphasis on agriculture as the source of all wealth, and the Camera lists' support for governmental control of the economy and taxes (Lombardin, 1996). Smith and Malthus used the phrase "fixed land and increasing people" to describe economic development in the context of their traditional theories of agriculture and population expansion. The law of diminishing returns kicks in when accessible land is exhausted by population expansion, resulting in a drop in real wages until they approach the subsistence level, at which point Malthusian equilibrium is achieved. 
Demand, according to Keynesians, is an essential condition for economic development to take place. Finally, they discovered via their study that aggregate demand management methods can and should be used to improve the performance of an economy's economy. Growing government expenditure, according to the Keynesian paradigm, leads to greater economic growth.

Some critics, such as Riedl (2010), argue that Keynesian government spending cannot spur economic development since it is either financed by taxes or borrowed from the public treasury. Taxation is a transfer of existing income, not a production of new buying power, according to the Federal Reserve System. Additionally, it serves as a deterrent to the creation of goods and the generating of revenue. Domestic borrowing has a negative effect on private sector investment and production, while foreign borrowing has a negative impact on the balance of payments. Moreover, Riedl (2010) argues that government spending can contribute to longterm growth if it is directed toward activities that increase productivity and employment, such as education (human capital development), physical capital (plant and equipment), tools, and other forms of capital investment, technology, public infrastructure, and utilities, and the establishment of contract enforcement institutions.

According to neoclassical growth models, fiscal policy by the government has no impact on national production. As a result, some models suggest that fiscal policy (intervention) by the government may help in mitigating market failures. The model developed by Harold Dammar sheds light on different growth patterns under the Keynesian paradigm. It is essential, for example, to maintain a country's production in terms of supply and demand balance while establishing an economy's growth rate equilibrium in order to achieve this. On the supply side, the level of GDP is determined by the amount of money saved. Investment, as well as the expansion of the nation's capital stock, is a key component of the demand for goods and services in the economy. As a result, the equilibrium rate of growth is achieved when the proportional change in production is matched with the ratio of savings to capital output. The economy is kept on a justified course of steady expansion, which has been maintained for many years. Deviations from the allowed development route will not self-correct, according to the model, if they occur. A phenomenon known as 'knife-edge instability' occurs when there are no self-correcting forces present in the dynamics of the models, and this is defined by the lack of self-correcting forces. Thus, the market-regulated development of the model is instabile and requires government action to stabilize it.

Among the most prominent economists who have disputed the connection between government expenditure and economic development is John Maynard Keynes. As an exogenous element, government expenditures, in Keynes's perspective, may be utilized as a policy instrument to promote economic development by increasing government spending. According to Keynesianism, government expenditure may have a positive impact on economic growth. As a consequence, an increase in government consumption is likely to result in an increase in employment, profitability, and investment as a result of multiplier effects on aggregate demand. Because of this, government spending raises aggregate demand, which in turn leads in higher production, depending on the size of the expenditure multiplier used to calculate output. Aside from that, Keynesian macroeconomics recognizes that a wide range of various kinds of public spending may contribute to economic development via the creation of multiplier effects on overall aggregate demand. Alternatives include the possibility that government consumption may crowd out private investment, slowing economic growth in the short run and decreasing long-term capital accumulation. There are differences between distortionary and nondiscriminatory taxes, as well as between productive and nonproductive expenditure according to endogenous growth research. Spending is categorized as productive if it is utilized 
as an argument in private production functions, and as unproductive if it is not used as an argument in private production functions (Barro \& Martin, 1992).

\section{Methods}

\section{Research Design}

Following the recommendations of Ihemeje, Umeh, and Ogbaje, an ex-post facto design will be used to investigate the impact of public capital expenditure on chosen economic performance indicators (2011) It is preferred when the variable or event being observed has already happened; as a result, an ex-post facto research design will be utilized in this study as a kind of descriptive research in order to gather information after the fact.

\section{Sources of Data Collection}

Several secondary sources, including the Central Bank of Nigeria's (CBN) Statistical Bulletin, the National Bureau of Statistics (NBS) journals, and other pertinent sources, will be used to gather data for this study, including the GDP, poverty rates, inflation rate, capital expenditure, and the real exchange rate, among other variables.

\section{Techniques of Data Analysis}

Prior to examining the relationship between public capital expenditure and selected economic performance indices, the Augmented Dickey-Fuller (ADF) approach was used to ensure that the variables' time series properties (stationarity) were in good shape before examining the relationship between capital expenditure and selected economic performance indices. To evaluate the impact of the explanatory factors on the dependent variables, the Autoregressive Distributed Lag model (ARDL) was used in conjunction with multiple regression and integration to find the effect of the dependent variables on the explanatory variables. The use of the Autoregressive Distributed Lag model (ARDL) in this research was prompted by the diverse order of integration seen in the unit root test, which led to the selection of the model. Many academics have shown interest in this method in earlier empirical investigations, such as Onwumere (2009), and it has been used by similar studies in Nigeria, such as Yekini (2001), Ezirim (2006), and Okafor (2009).

\section{Model Specification}

$\mathrm{Y}=\mathrm{BO}+\mathrm{B} 1+\mathrm{ei}$

Where;

$\mathrm{Y}=$ Dependent Variables

$\mathrm{B} 0=$ intercept of $\mathrm{Y}$

Y= Dependent Variable

B1,2,3 are Parameters

ei=Stochastic Variables

In specifying the models to be used in this study, the following abbreviations will be applied;

INF Inflation Rate

PVR Poverty Rate

GDP Gross Domestic Product Growth Rate

CAPEXP Capital Expenditure

RER Real Exchange Rate 
The above model has been adopted and modified mathematically as follows;

$$
\begin{aligned}
& \text { GDPGR }=\beta 0+\beta 1 \text { CAPEXP }+\beta 2 \text { RER }+ \text { ei } \\
& \text { INFR }=\beta 0+\beta 1 \text { AAPXP }+\beta 2 \text { RER }+ \text { ei } \\
& \text { POVTR }=\beta 0+\beta 1 \text { CAPEXP }+\beta 2 \text { RER }+ \text { ei }
\end{aligned}
$$

\section{Results and Discussion}

\section{Data Analysis and Interpretation of Results}

All of the data in Table 1 was supplied by the United States government, including the gross domestic product, capital expenditure, poverty rate, inflation rate, and currency exchange rate. The gross domestic product (GDP) had variations in its growth rate throughout the study period (1981 to 2015). According to the statistics from 1981 to $1985: 1.11 \%, 1.99$ percent, 0.79 percent, 0.92 percent, 2.96 percent, 0.79 percent, 0.92 percent, 2.96 percent and 1.211 percent. Furthermore, it fluctuated between 0.46 percent in 1986 and 3.25 percent in 1992. A steady increase in the value of gross domestic product occurred from 1993 and 1995. (1.11 percent, 1.44 percent and 2.24 percent respectively).

The GDP increased steadily from 1997 to 2000, when it fell to 0.77 percent, where it remained until the end of the study period, ranging from 2.21 percent in 2002 to 0.61 percent in 2003 to 2.04 percent in 2004 to 1.23 percent in 2005 to 1.29 percent in 2006 to 0.67 percent in 2007 to 1.42 percent in 2008 to 0.83 percent in 2009 to 2.01 percent in 2010 to 0.81 percent in 2011 . The GDP increased steadily from 1997 to 2000, when it fell to 0.77 percent, where it.

Capital spending by the government varied between N6.57 million in 1981 and N6.42 million in 1982, N4.89 million in 1983, N4.1 million in 1984 and N5.46 million in 1985, with 1981 being the highest at N6.57 million and 1982 being the lowest. During the period 1986 to 2015, the total amount of government capital spending rose from N8.53 million to N1312.61 million.

Despite a little decrease in the poverty rate values in 1982, 1989, 1992, 2002, and 2009, the overall pattern of movement in the poverty rate values in Nigeria showed that poverty is rising across the nation. From 2010 to the conclusion of the research period, the geometric growth rate was found to be increasing steadily. Over the research period, the inflation rate fluctuated considerably, ranging from 20.9 percent in 1981 to 9.9 percent in 2015.

Over the course of the research, inflation reached its zenith in 1995, which also happened to coincide with the beginning of the geometric rise in poverty rates after previous periods of arithmetic movement. When comparing the years 1981 and 1985, the exchange rate remained steady, ranging between $0.63 \mathrm{~N} / \$$ and $0.89 \mathrm{~N} / \$$. Over the period 1986 to 1993 , the value of the naira fluctuated, most likely as a consequence of the 1986 Structural Adjustment Programme (SAP). Between 1994 and 1998, the value of the Naira in relation to the US Dollar seemed to be constant. The exchange rate fluctuated between 1999 and the conclusion of this research. If we look at the trend of the variables used in this research, we can see that the results do not always match with the theoretical assumptions, which is a source of confusion. Following the presentation of the data for analysis, the researchers used descriptive statistics to investigate the socioeconomic characteristics of the variables, as indicated in Table 1 below. 


\section{Descriptive Statistics}

Table 1. Descriptive statistics based on the variables used in the analysis

\begin{tabular}{|c|c|c|c|c|c|}
\hline Variables & $\begin{array}{c}\text { GDPgrowth } \\
\text { rate (\%) }\end{array}$ & $\begin{array}{c}\text { Capital } \\
\text { Expenditure } \\
(\mathbf{M})\end{array}$ & $\begin{array}{c}\text { Poverty rate } \\
(\mathbf{\%})\end{array}$ & Variables & Exchange rate \\
\hline Mean & 1.434143 & 384.4611 & 53.89429 & 19.60286 & 72.15707 \\
\hline Median & 1.211000 & 241.6900 & 54.40000 & 12.50000 & 22.05000 \\
\hline Maximum & 4.625000 & 1312.610 & 76.00000 & 72.80000 & 172.3210 \\
\hline Minimum & 0.376000 & 4.100000 & 27.50000 & 5.400000 & 0.630000 \\
\hline Std. Dev. & 0.890797 & 415.3088 & 13.51300 & 17.12587 & 66.76271 \\
\hline Skewness & 1.671999 & 0.823079 & -0.294445 & 1.600805 & 0.195665 \\
\hline Kurtosis & 6.142739 & 2.300056 & 2.331943 & 4.633788 & 1.261328 \\
\hline Jarque-Bera & 30.71124 & 4.666315 & 1.156594 & 18.84103 & 4.631839 \\
\hline Probability & 0.000000 & 0.096989 & 0.560853 & 0.000081 & 0.098675 \\
\hline Sum & 50.19500 & 13456.14 & 1886.300 & 686.1000 & 2525.497 \\
\hline Sum Sq. Dev. & 26.97964 & 5864368. & 6208.439 & 9972.050 & 151546.8 \\
\hline Observations & 35 & 35 & 35 & 35 & 35 \\
\hline
\end{tabular}

Source: computed by the author from CBN statistical bulletin 2008 and 2015, using Eview 9.0

Using data from 35 years of analysis, Table 1 shows that the cumulative values of GDP growth rate, capital expenditure, poverty rate, and inflation rate were respectively 50.19 percent, N13456.14 million, 1886.30 percent, and 686.1 percent during the 35 years of data used in the analysis. Average annual GDP growth rates of 1.43 percent, capital expenditure of N384.46 million, poverty rate of 53.89 percent, and inflation rate of 19.60 percent were all recorded in the first quarter of 2018.

GDP growth rates reached a high of 4.62 percent in 2015 and a low of 0.37 percent in 1981, respectively. Between 2015 and 1981, capital expenditure reached a high of N1312.61 million and a low of N4.10 million in the period under consideration. Additionally, the poverty rate reached a high of 76.0 percent and a minimum of 27.5 percent during the course of the research period, respectively (between 1981 and 2015). Inflation rates reached a high of 72.8 percent in 2015 and a low of 5.40 percent in 1981, respectively. Between 2015 and 1981, the exchange rate hit a high of $172.3210 \mathrm{~N} / \$$ and a low of $0.630000 \mathrm{~N} / \$$, reaching a height of $172.3210 \mathrm{~N} / \$$ in 2015. Between 2015 and 1981, capital expenditure reached a high of N1312.61 million and a low of N4.10 million in the period under consideration.

As shown in Table 1, the skewness values of the GDP growth rate, capital expenditure, poverty rate, and inflation rate are all 1.672, $0.823,-0.29$, and 1.60 for the corresponding time periods under consideration. Except for the poverty rate (which showed a downward trend), all of the variables in the research had a positive value curve distribution, according to the results. This shows that as time passes, values tend to rise in value as well. The poverty rate, on the other hand, has a skewness score of -0.29 , showing a negative distribution of the value curve, indicating that values tend to decline as time passes. The unit root test must be carried out in order to determine whether or not the variables under consideration are stationary. When you look at the descriptive statistics table in Table 1 in more depth, you will see that the data were evenly distributed 
Table 2. Stationarity Properties of the Variable Used in the Analysis

\begin{tabular}{|c|c|c|c|}
\hline \multicolumn{4}{|c|}{ Augmented Dickey-Fuller } \\
\hline Variables & 1(0) Level & 1(1) FD & Order of Integration \\
\hline GDP growth rate & -7.765285 & $-8.609866^{* * *}$ & $\mathrm{I}(0)$ \\
\hline Capital expenditure & 0.536145 & $-7.305632^{* * *}$ & $\mathrm{I}(0)$ \\
\hline Poverty rate & -1.378090 & $-6.075139^{* * *}$ & $\mathrm{I}(0)$ \\
\hline Inflation rate & -2.787913 & -5.618758 & $\mathrm{I}(1)$ \\
\hline Exchange rate & -0.148237 & -6.047158 & $\mathrm{I}(1)$ \\
\hline $\begin{array}{c}\text { Test critical values: } \\
\text { 1\% level }\end{array}$ & -3.639407 & -4.273277 & \\
\hline 5\% level & -2.951125 & -3.557759 & \\
\hline 10\% level & -2.614300 & -3.212361 & \\
\hline
\end{tabular}

First, the statistical characteristics of the data series, including tests for stationary state, are investigated. This is followed by estimation of the economic models described in this research. Results of the Augmented Dickey Fuller (ADF) unit root test on the unlogged variables used in the study are shown in Table 2. Table 3 shows the cointegrating form of the relationship between the variables included in the model.

Table 3. cointegration analysis of GDP growth model

\begin{tabular}{|c|c|c|c|c|}
\hline \multicolumn{7}{|c|}{ Cointegrating Form } \\
\hline Variable & Coefficient & Std. Error & t-Statistic & Prob. \\
\hline $\mathrm{D}($ GDPGR(-1)) & 0.198415 & 0.146263 & 1.356558 & 0.1917 \\
\hline $\mathrm{D}($ CAPE) & -0.002422 & 0.000687 & -3.523071 & $0.0024 * * *$ \\
\hline $\mathrm{D}($ INFR) & 0.021342 & 0.008483 & 2.515802 & $0.0216^{* *}$ \\
\hline $\mathrm{D}(\mathrm{INFR}(-1))$ & 0.037739 & 0.009699 & 3.890937 & $0.0011^{* * *}$ \\
\hline $\mathrm{D}($ POVR $)$ & 0.041147 & 0.025199 & 1.632883 & 0.1199 \\
\hline $\mathrm{D}($ POVR(-1)) & 0.002426 & 0.029067 & 0.083472 & 0.9344 \\
\hline $\mathrm{D}($ POVR(-2)) & 0.016865 & 0.027903 & 0.604424 & 0.5531 \\
\hline $\mathrm{D}($ POVR(-3)) & 0.033062 & 0.025165 & 1.313813 & 0.2054 \\
\hline D(RER) & 0.007970 & 0.005403 & 1.475042 & 0.1575 \\
\hline CointEq(-1) & $\mathbf{- 2 . 0 2 0 8 3 3}$ & $\mathbf{0 . 2 6 1 0 2 6}$ & $\mathbf{- 7 . 7 4 1 8 7 9}$ & $\mathbf{0 . 0 0 0 0} * * *$ \\
\hline
\end{tabular}

Source: Computed by the author using E-view 9.0. Note ** and *** stand for $5 \%$ and $1 \%$ respectively.

As seen in Table 3, there is cointegration between GDP and capital expenditure, indicating that the two variables have a long term relationship. On the other hand, inflation was significant at the 5\% level, showing that the variables were cointegrating. Additionally, while the poverty rate did not exhibit a cointegrating sign in the analysis, capital expenditure was significant, implying the likelihood of a long term relationship between the variables.

Table 4. blong run cointegrating form of GDP growth model

\begin{tabular}{|c|c|c|c|c|}
\hline \multicolumn{5}{|c|}{ Long Run Coefficients } \\
\hline Variable & Coefficient & Std. Error & t-Statistic & Prob. \\
\hline CAPE & -0.001198 & 0.000308 & -3.896587 & $0.0011^{* * *}$ \\
\hline INFR & -0.009360 & 0.005230 & -1.789572 & $0.0904 *$ \\
\hline POVR & -0.011322 & 0.010283 & -1.101039 & 0.2854 \\
\hline RER & 0.003944 & 0.002613 & 1.509167 & 0.1486 \\
\hline C & 2.374387 & 0.448798 & 5.290543 & $0.0000 * * *$ \\
\hline
\end{tabular}

Source: Computed by the author using E-view $9.0 *$ and *** stand for $10 \%$ and $1 \%$ respectively.

Copyright $@$ 2021, Journal of Asian Multicultural Research for Economy and Management Study, Under the license CC BY-SA 4.0 
Stevenson's (1988) method for the cointegration analysis ARDL is used to evaluate economic performance. This is due to the fact that the aim of cointegration analysis is to search for evidence of a long-run connection, and it is thus fair to assume that the actual and projected rates of equilibrium adjustment are the same in the long run. In this research, the maximum number of lags is one, due to the large sample size of 35 years.

The findings of the ARDL cointegration are consistent with those obtained by Anari and Kolari (2002), but they differ from those obtained by Zhou and Clementa (2010). For another option, and given that the connection extends from capital expenditure to GDP growth, the P-value and t-statistic values in Tables 3.43 and 4.44 suggest that the cointegration findings are very strong. Specifically, it demonstrates that the rates of capital expenditure and GDP growth are cointegrated at the 95 percent level of significance. CointEq(-1) shows that the equilibrium adjustment mechanism is properly signed and that the variables integrated to order 1 have the potential to return to long run equilibrium in the shortest period of time feasible (-2.020833).

After that, the researchers conducted regression analysis to assess the impact of public capital expenditure on economic development.

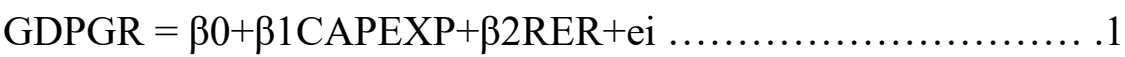

Table 5. regression result of the GDP growth model

\begin{tabular}{|c|c|c|c|c|}
\hline Variable & Coefficient & Std. Error & t-Statistic & Prob.** \\
\hline GDPGR(-1) & -0.586152 & 0.178741 & -3.279341 & $0.0032^{* * *}$ \\
\hline GDPGR(-2) & -0.235195 & 0.193697 & -1.214240 & 0.2365 \\
\hline GDPGR(-3) & -0.341952 & 0.189536 & -1.804152 & $0.0838^{*}$ \\
\hline GDPGR(-4) & -0.342632 & 0.172445 & -1.986901 & $0.0585^{*}$ \\
\hline CAPE & -0.001856 & 0.000761 & -2.440137 & $0.0224^{* *}$ \\
\hline RER & 0.001572 & 0.004582 & 0.343026 & 0.7346 \\
\hline C & 4.370353 & 0.883455 & 4.946888 & $0.0000^{* * *}$ \\
\hline R-squared & 0.463468 & & & \\
\hline Adjusted R-squared & 0.329335 & & & \\
\hline F-statistic & $3.455283^{* *}$ & & & \\
\hline $\begin{array}{c}\text { Prob(F-sta } \\
\text { +tistic) }\end{array}$ & 0.013268 & & & \\
\hline Durbin-Watson stat & 1.928378 & & & \\
\hline
\end{tabular}

Source:Researcher's compilation from E-view 9.0 wind processed (FD-first difference). $*, * *$ and $* * *$ represents $10 \%, 5 \%$ and $1 \%$ levels of significance.

As shown in Table 4.5, the GDP growth rate in the previous era was greater than the GDP growth rate in the current period. This is properly reflected by the t-statistic of 3.279341 and the p-value of 0.0032 , which are both accurate. The policy implication is that, as time progresses, there is evidence of an improvement in economic conditions. This model was selected as the lead model because to its high coefficient of multiple determinations (R2= 0.463468), the fact that its signs correspond to a priori expectations, and the fact that it included an adequate amount of important variables. When the explanatory variables of the model were combined, they explained about 46.34 percent of the observed variance in the value of GDP growth rate. Because the coefficient of many determinations is high and near to unity, it may be used to determine whether or not a model is good.

Specifically, an f-statistic of 3.455283 shows that the study's model was well-formulated at the 5 percent level of significance, and a Durbin Watson value of 1.9283 verifies that there is no serial correlation among the study's variables. 
The amount of capital expenditure (CAE) was determined to be significant, and it had an impact on the rate of GDP growth over the reference time period. Capital expenditure coefficient (0.001856 ) at the $5 \%$ level of significance shows how a reduction in capital expenditure leads to a commensurate fall in GDP growth rate throughout the course of the research. In accordance with the a priori/theoretical premise that a percentage decrease in capital investment leads in a proportionate reduction in economic performance and vice versa, the findings of this study are compatible with that notion. The exchange rate was shown to be both positive and insignificant in explaining changes in the dependent variable throughout the course of the research, with a coefficient value of 0.001572 .

When these results were compared to those of previous studies, it was discovered that they came to contradictory conclusions. Because the effect of government capital investment on Nigeria's economic performance has been shown to be both conceptually complicated and empirically ambiguous, this is particularly true. The results of the study were found to be in conflict with those of Folster \& Henrekson (2021), according to the researchers (2003). It is shown in their research by Nurudeen \& Usman (2010) that higher government capital expenditure may result in enhanced economic development in Nigeria, as well as better corporate performance throughout the country's many activity sectors. Amounts spent on road building, hospital development, and educational facilities are examples of capital investment, which always leads to increases in employment status and economic growth over a predetermined period of time. As stated by Mitchell (2012), one of the main goals of government spending is to promote economic activity and stability over the long run. Because of the present government capital spending that seems to be unproductive, this research is very relevant now. Additionally, the results of Muritala \& Taiwo (2011)'s empirical research on government capital spending are corroborated by this study.

The study employed an Autoregressive Distributed Lag technique to ascertain the effect of public capital investment on the performance of the Nigerian economy, as measured by GDP growth rate. The result indicated that the t-statistic value was more than the crucial value (2.0) by -2.440 and the $p$-value was less than the critical value by 0.0224 . (0.05). As a result of this finding, the study concluded that capital investment had a considerable impact on Nigeria's economic performance as measured by GDP growth rate

\section{Conclusion}

The purpose of this research was to determine the effect of public capital spending on the development of the Nigerian economy. In conclusion, it can be said that public capital expenditures had a substantial impact on the rate of GDP growth over the time period under consideration. It means that better economic activities oriented toward growth are judged on the basis of their efficiency and productivity, which is one of the yardsticks for improvement. As a result, the government should guarantee that capital expenditures are appropriately handled in a way that will increase the nation's productive capacity while also accelerating economic growth.

\section{References}

Barro, R. (1990). government spending in a simple Endogenous Growth. Journal of Political Economy (98)103-107.

Barro, R., and Martin, I. (1992). "Public Finance in Models of Economic Growth" Review of Economic Studies, 59(3): 645-661.

Branson, W. H. (2002). Macroeconomic theory and policy", 2nd Edition, Nice Printing Press, Delhi. 
Ezirim, C.B (2006). Explaining the size of Public expenditure in less developed countries. Theory and Empirical Evidence from Nigeria. Nigerian Journal of Banking and Finance UNEC (6)

Folster S, \& Henrekson M, (2001). Growth Effects of Government Expenditure and Taxation in Rich Countries European Economic Review (8),45, 1501-1520.

Muritala, T, \&Taiwo, A. (2011). Government expenditure and economic development: Empirical evidence from Nigeria. European Journal of Business and Management, 3(9), 2011

Nurudeen, A. \& Usman, A. (2010). "Government Expenditure and Economic Growth in Nigeria" (1970-2008): A Disaggregated Analysis for Developing Countries, JEL Publications.

Obi, E. \& Obi, T. (2014) 'Impact of Government Expenditure on Education, the Nigerian Experience

Obi, E. (2011). Budget deficit, external debt and economic growth in Nigeria. Applied econometrics and international development. Vol.6 No.3 p.11 - 13.

Okafor, M.C. (2015). Effect of federal government expenditure on social sector outcomes in Nigeria, unpublished M.sc Thesis. Institute for development studies, University of Nigeria, Enugu Campus.

Onakoya, A.B, \& Osoba, A.M. (2012). Investment in telecommunications infrastructure and Nigerian economic growth. British Journal of Economics, Management and Trade 2(4): 309-326, 2012.

Riedl, B.M. (2010), Why Government Spending Does Not Stimulate Economic Growth: Answering the Critics, The Heritage Foundation, 2354, 1-9

Tsauni, A.M. (2007). 'Infrastructure and Business Performance in Nigeria: Evidence from manufacturing Sector (1985-2004). Conference Paper presented at Department of Business Administration Annual Conference. Bayero University, Kano 